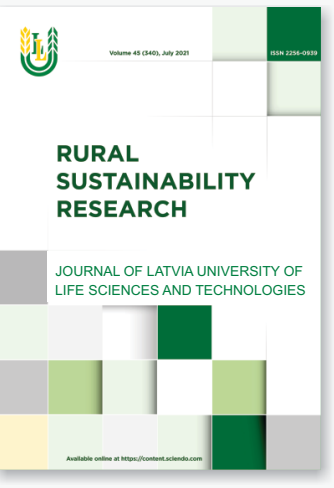

\title{
Slaughter Results, Meat Chemical Composition and pH of Aberdinangus, Hereford and Limousin bulls
}

\author{
*Inga Muizniece, Daina Kairisa \\ Latvia University of Life Sciences and Technologies, 2 Liela street, Jelgava, Latvia
}

\begin{abstract}
Beef production must combine the interests of both producers and consumers, taking into account the sustainable use of environmental resources. The aim of the study was to analyze and compare the slaughter results, meet chemical composition and pH value of three beef breeds - Aberdinangus (AA), Hereford (HF) and Limousin (LI) bulls. The bulls were fattened on Latvian and Lithuanian farms, mainly using grass forage.

The breed and age of bulls before slaughter significantly affected all slaughter results, except for fat class. From the meat chemical composition traits, the bull breed and age before slaughter had a significant effect only on the protein content. LI bulls showed the highest carcass weight $301.1 \pm 6.8 \mathrm{~kg}(\mathrm{p}<0.05)$, dressing percentage $58.2 \pm 1.1 \%(\mathrm{p}<0.05)$ and conformation score $3.56 \pm 0.18$ points. The best fattened carcasses were obtained from AA bulls $-2.43 \pm 0.20$ points. Muscle samples of musculus longissimus (M. longissimus) bulls of LI breed showed higher content of moisture $(72.0 \pm 1.0 \%)$, protein $(23.0 \pm 0.2 \%)$, ash $(1.1 \pm 0.0 \%)$ and cholesterol $\left(56.7 \pm 6.6 \mathrm{mg} 100 \mathrm{~g} \mathrm{~g}^{-1}\right)$. AA breed bulls showed higher total fat $(6.6 \pm 1.2 \%)$ and iron content $(13.1 \pm 0.6 \mathrm{mg})$. The highest $\mathrm{pH}$ was observed in the meat obtained from AA bulls $-6.0 \pm 0.1$, LI and HF breed bulls showed $\mathrm{pH}$ $5.8 \pm 0.0$ and $5.8 \pm 0.1$ respectively. Correlation analysis showed a significant, strong positive correlation between cold carcass weight and dressing percentage for AA and LI bulls, $\mathrm{r}=0.90$ and $\mathrm{r}=0.88$, respectively. For LI breed bulls, a strong positive correlation was also found between the cold carcass weight and the conformation score $(\mathrm{r}=0.98, \mathrm{p}<0.01)$.
\end{abstract}

Key words: beef cattle, slaughter results, meat chemical composition, $\mathrm{pH}$.

\section{Introduction}

Beef production must keep pace with modern trends, adapting to the interests of the environmental protection and consumers. Fattening cattle with grass forage is considered to be an environmentally friendly meat production solution that eliminates direct competition for human consumption (feed no food) and ensures the sustainable use of resources (Chassot, 2008). There is a growing interest from consumers in the composition of food consumed and its effects on health, as well as in ethical aspects, giving a rise to interest in the conditions under which food is obtained. Therefore, research work should focus not only on the study of the optimization of meat production, which is useful for the producer, but also on the study of the chemical composition of meat and the factors influencing it, to ensure the interests of consumers.

The productivity of beef cattle depends on the breed chosen for breeding, which has been confirmed in the results of many studies (Coyne, Evans, \& Berry, 2019; Hollo et al., 2012; Muižniece \& Kairiša, 2016; Nogalski et al., 2014; Toro et al., 2009). It has been proven that cattle of the Continental
European type (for example, LI) are generally larger in mature size, with a higher live weight, a higher live weight gain, a slaughter weight, a better conformation and produce carcasses with less fat. British type breeds (for example, AA and HF), when compared to Continental European breeds, are generally smaller in mature size, with less live weight and live weight gain, but produce carcasses with better fat cover and intramuscular fats. Cattle of British type breeds are suitable for more extensive fattening conditions, because they have historically been designed for efficient use of grasslands and they are suitable for more extreme housing conditions (Pesonen \& Huuskonen, 2015; Pesonen et al., 2013b; Sexten etal., 2012).

The chemical composition of meat is mainly influenced by the fattening technology of cattle, including their place of origin and fattening, age, sex, breed and muscle group (Gagaoua et al., 2016; Giuffrida-Mendoza et al., 2007; Hollo et al., 2007; Littledike, Wittum, \& Jenkins, 1995; Lopez Alonso et al., 2000; Mateescu et al., 2013; Tizioto et al., 
2015). Beef is rich in nutrients and is a source of essential amino acids, vitamins (A, B6, B12, D) and minerals, including iron, zinc and selenium (Biesalski, 2005; Nohr \& Biesalski, 2007). In red meat, iron is in a form that is easily absorbed by the human body, so beef is one of the most suitable sources of iron intake in the daily diet (Mateescu et al., 2013). Cholesterol is considered a risk factor for cardiovascular disease and promotes atherosclerotic changes in the body. Studies performed so far have shown that the cholesterol content of meat is mainly influenced by the feeding stuffs used in cattle fattening and that the breed has no significant effect on its changes (Brugiapaglia, Lussiana, \& Destefanis, 2014; Mungure et al., 2020; Wheeler et al., 1987).

The aim of the study was to analyze and compare the slaughter results, meet chemical composition and $\mathrm{pH}$ value of AA, HF and LI bulls.

\section{Materials and Methods}

The study used data from pure-bred bulls slaughtered in

\section{Research material and features}

\begin{tabular}{|c|c|c|c|}
\hline $\begin{array}{l}\text { Breed and breed } \\
\text { abbreviation }\end{array}$ & $\begin{array}{c}\text { Number of } \\
\text { bulls }\end{array}$ & Traits collected before slaughter & Traits collected after slaughter \\
\hline Aberdinangus (AA) & 7 & \multirow{3}{*}{$\begin{array}{l}\text { - Birth date } \\
\text { - Age before slaughter, days } \\
\text { - Live weight before slaughter, kg }\end{array}$} & \multirow{3}{*}{$\begin{array}{l}\text { - Cold carcass weight, kg } \\
\text { - Carcass conformation and } \\
\text { fatness development according } \\
\text { to EUROP classification } \\
\text { - pH measurement in } \\
\text { slaughterhouse } 24 \mathrm{~h} \text { after } \\
\text { slaughter }\end{array}$} \\
\hline Hereford (HF) & 11 & & \\
\hline Limousin (LI) & 9 & & \\
\hline
\end{tabular}

The quality assessment of the carcasses was performed in accordance with the EUROP classification established by Regulation (EU) No 1308/2013, the assessment was performed by a certified specialist of the slaughterhouse. EUROP letters with the following meanings are used to indicate muscular development: $\mathrm{E}$ - excellent (numerical designation - 5), U - very good (4), R - good (3), O - average (2), $\mathrm{P}$ - weak (1) developed musculature. The evaluation of fatness development is marked with numbers from 1 to 5 , where 1 - very low, 2 - low, 3 - medium, 4 - high, 5 - very high.

After slaughter carcasses were chilled 24 hours at the
2018 and 2019 in the slaughterhouse 'Agaras' (Lithuania) within the framework of the project 'Baltic Grassland Beef' implemented in the Baltic States. The bulls were fattened on Latvian and Lithuanian farms according to the project conditions, mainly using grass forage. The data of three beef breed (AA, HF, LI) bulls slaughter, meat chemical composition and $\mathrm{pH}$ were used as the research material.

Information on the date of birth and belonging to the breed was obtained from the databases of the Latvian Agricultural Data Center and the Lithuanian Beef Cattle Breeders and Improvers Association. Slaughter results: cold carcass weight, conformation and fat class, obtained from slaughterhouse UAB 'Agaras' protocols. Bulls that had reached a live weight of at least $490 \mathrm{~kg}$ before slaughter were selected for the study.

The number of bulls used in the study and the evaluated traits are summarized in Table 1. temperature of $+3^{0} \mathrm{C}$, then the $\mathrm{pH}$ of the meat was measured. The measurement was taken in the loin section using a ProfiLine $\mathrm{pH}$ meter 3310.

For the analysis of the chemical composition of the meat, the samples were prepared from the $M$. longissimus, frozen and when the required amount of samples was collected, delivered to the laboratory of the Scientific Institute of Food Safety, Animal Health and Environment 'BIOR'. The samples were delivered to the laboratory frozen using a cold bag.

The chemical composition analyzed in the sample and the methods used are summarized in Table 2.

The analyzed chemical composition of M. longissimus and methods used in the laboratory

\begin{tabular}{|l|c|}
\hline \multicolumn{1}{|c|}{ Chemical composition } & Method of analysis \\
\hline Moisture, \% & LVS ISO 1442:1997 \\
\hline Fat, $\%$ & LVS ISO 1443:1973 \\
\hline Protein, \% & LVS ISO 937:1978 \\
\hline Ash, \% & ISO 936:1998 \\
\hline
\end{tabular}




\begin{tabular}{|l|l|}
\hline Cholesterol, ${\mathrm{mg} 100 \mathrm{~g}^{-1}}^{-1}$ & BIOR-T-012-132-2011 \\
\hline Iron, $\mathrm{m} \mathrm{kg}^{-1}$ & BIOR-T-012-148-2013 \\
\hline
\end{tabular}

Bull breed, age before slaughter and live weight before The factor gradation classes are given in Table 3 . slaughter were analyzed as factors influencing the results.

\section{Factors influencing the studied features, gradation classes and characteristics}

\begin{tabular}{|c|c|c|}
\hline Factors & $\begin{array}{c}\text { Gradation } \\
\text { classes }\end{array}$ & Characteristics \\
\hline Breed & 3 & $1-$ AA; $2-\mathrm{HF} ; 3-$ LI. \\
\hline Age before slaughter & 3 & $1-$ till 550 days; $2-551-620$ days; $3-621$ and more days. \\
\hline Live weight before slaughter & 3 & $1-$ till $515 \mathrm{~kg} ; 2-516-540 \mathrm{~kg} ; 3-541$ and more kg. \\
\hline
\end{tabular}

After slaughter, the obtained dressing percentage

is calculated, according to the formula:

$$
d=\frac{C c}{L w} \times 100
$$

were $\quad \mathrm{d}-$ dressing percentage, $\%$

$\mathrm{Cc}$ - cold carcass weight, $\mathrm{kg}$

$\mathrm{Lw}$ - live weight before slaughter, $\mathrm{kg}$

Data were analyzed using SPSS software. Average values, standard error $(\mathrm{x} \pm \mathrm{Sx})$ and coefficient of variation $(\mathrm{V}, \%)$ results were calculated. The influence of fixed factors on the slaughter results and meat chemical composition has been determined using one-way analysis of variance (ANOVA). The significance of the differences in the obtained results between the bull breeds was tested by t-test. Different letters $(a, b, c)$ on figures and tables mark significant differences at $\mathrm{p}<0.05$. For traits relationship, Pearson correlation analysis determination

\section{Results and Discussion}

At the beginning of the analysis of the obtained results, the influence of the fixed factors, bull breed, age and live weight, was determined. No significant effect on the live weight of bulls before slaughter was confirmed. This can be explained by the fact that the choice of bulls for the study was mainly related to the achieved live weight. Minimum bull live weight was $494 \mathrm{~kg}$, but maximum - $569 \mathrm{~kg}$, coefficient of variation was $3.7 \%$.

It was found that the breed and age of bulls before slaughter significantly affected all slaughter results, except for fat class (Table 4). Similar results of the influence of the studied factors were obtained in a study conducted in Latvia comparing the results of slaughtering bulls of Blond d'Aquitaine, Hereford, Simmental and crosses of different breeds (Muizniece \& Kairisa, 2016).

From the analyzed meat chemical composition traits, the bull breed and age before slaughter had a significant effect on the protein content, but none of the analyzed factors had a significant effect on the other meat chemical composition indicators.

Analysis of factors influencing slaughter results and chemical composition of meat

\begin{tabular}{|c|c|c|}
\hline \multirow{3}{*}{ Traits } & \multicolumn{2}{|c|}{ Factors } \\
\hline & breed & age before slaughter \\
\hline & \multicolumn{2}{|c|}{$\mathrm{p}<0.001$} \\
\hline Age before slaughter, days & $* * *$ & $\ldots$ \\
\hline Live weight before slaughter, $\mathrm{kg}$ & $* * *$ & $* * *$ \\
\hline Cold carcass weight, $\mathrm{kg}$ & $* * *$ & $* * *$ \\
\hline Dressing percentage, $\%$ & $* * *$ & $* * *$ \\
\hline Conformation score, points & $* * *$ & $* * *$ \\
\hline
\end{tabular}




\begin{tabular}{|c|c|c|}
\hline Fat score, points & $\mathrm{ns}$ & $\mathrm{ns}$ \\
\hline Moisture, $\%$ & $\mathrm{~ns}$ & $\mathrm{~ns}$ \\
\hline Fat, $\%$ & $\mathrm{~ns}$ & $\mathrm{~ns}$ \\
\hline Protein, $\%$ & $* * *$ & $\mathrm{~ns}$ \\
\hline Ash, $\%$ & $\mathrm{~ns}$ & $\mathrm{~ns}$ \\
\hline Cholesterol, $\mathrm{mg} 100 \mathrm{~g}^{-1}$ & $\mathrm{~ns}$ & $\mathrm{~ns}$ \\
\hline Iron, $\mathrm{mg} \mathrm{kg-1}$ & $\mathrm{ns}$ & $\mathrm{ns}$ \\
\hline $\mathrm{pH}$ & $\mathrm{ns}$ & \\
\hline
\end{tabular}

$* * *$ - significant

ns - non significant

Taking into account the influence of the breed, further data analysis was performed by groups of breeds, without singly separating age groups. The breeds used in the study are not equally fast-growing. The LI breed has a faster growth rate when compared to AA and HF breeds, as evidenced by the results of research by other scientists (Hickey et al., 2014; Pesonen \& Huuskonen, 2015).

The comparison of slaughter results between the bull breeds used in the study is summarized in Table 5 .

\section{Slaughter results by bull breeds}

\begin{tabular}{|c|c|c|c|c|c|c|}
\hline \multirow{3}{*}{ Traits } & \multicolumn{6}{|c|}{ Breed } \\
\hline & \multicolumn{2}{|c|}{$\mathrm{AA}(\mathrm{n}=7)$} & \multicolumn{2}{|c|}{$\mathrm{HF}(\mathrm{n}=11)$} & \multicolumn{2}{|c|}{$\mathrm{LI}(\mathrm{n}=9)$} \\
\hline & $\mathrm{x} \pm \mathrm{Sx}$ & $\mathrm{V}, \%$ & $\mathrm{X} \pm \mathrm{Sx}$ & $\mathrm{V}, \%$ & $\mathrm{x} \pm \mathrm{Sx}$ & $\mathrm{V}, \%$ \\
\hline Age before slaughter, days & $612.6 \pm 10.35^{\mathrm{a}}$ & 4.5 & $683.0 \pm 18.52^{\mathrm{b}}$ & 9.0 & $544.0 \pm 7.88^{\mathrm{c}}$ & 4.4 \\
\hline $\begin{array}{l}\text { Live weight before } \\
\text { slaughter, } \mathrm{kg}\end{array}$ & $536.3 \pm 4.43^{\mathrm{ab}}$ & 2.2 & $541.3 \pm 5.96^{\mathrm{a}}$ & 3.7 & $516.9 \pm 5.59^{\mathrm{b}}$ & 3.2 \\
\hline Coldcarcass weight, $\mathrm{kg}$ & $298.2 \pm 5.51^{\mathrm{ab}}$ & 4.9 & $280.0 \pm 4.56^{\mathrm{a}}$ & 5.4 & $301.0 \pm 6.77^{\mathrm{b}}$ & 6.6 \\
\hline Dressing percentage, $\%$ & $55.6 \pm 0.96^{\mathrm{a}}$ & 4.6 & $51.7 \pm 0.62^{\mathrm{b}}$ & 4.0 & $58.2 \pm 1.08^{\mathrm{a}}$ & 5.6 \\
\hline
\end{tabular}

$\mathrm{a} b \mathrm{c}-$ significant differences between the study groups, $\mathrm{p} \leq 0.05$

Bulls of the HF breed were significantly older, higher live weight before slaughter, but lower slaughter weight and dressing percentage compared to the LI breed. The difference in age before slaughter was 139 days, live weight $-24.4 \mathrm{~kg}$, slaughter weight $-21.0 \mathrm{~kg}$ and dressing percentage $-6.5 \%$ $(\mathrm{p}<0.05)$. Compared to AA breed bulls, significant differences were obtained for age before slaughter 70.4 days and slaughter yield $-3.9 \%(\mathrm{p}<0.05)$. Significant differences were obtained for LI and AA breed bulls in age before slaughter, LI breed bulls were 68.6 days younger $(p<0.05)$. The values of the coefficients of variation of the studied features are small to medium. The largest variation was obtained for the slaughter age of HF breed bulls $9.0 \%$, but the live weight before slaughter was equalized in all groups.

The results published in the literature show that the dressing percentage is influenced by the carcass conformation score, the more muscular the carcass, the higher the dressing percentage (Stimbirys et al., 2016). The results of our study also confirm this.

The highest evaluation of carcass conformation was obtained for LI breed bulls, on average $3.56 \pm 0.18$ points (Figure 1).

Bulls of this breed had the highest dressing percentage $(58.2 \pm 1.08 \%)$. Significantly lower carcass conformation score was in HF breed bulls, on average $2.64 \pm 0.15$ points, difference with LI bulls was 0.92 points $(p<0.05)$. Studies have shown similar results, showing that cattle of Continental European type breeds show higher slaughter weight, dressing percentage and better conformation score to British type breeds (Coyne, Evans, \& Berry, 2019; Pesonen \& Huuskonen, 2015). 


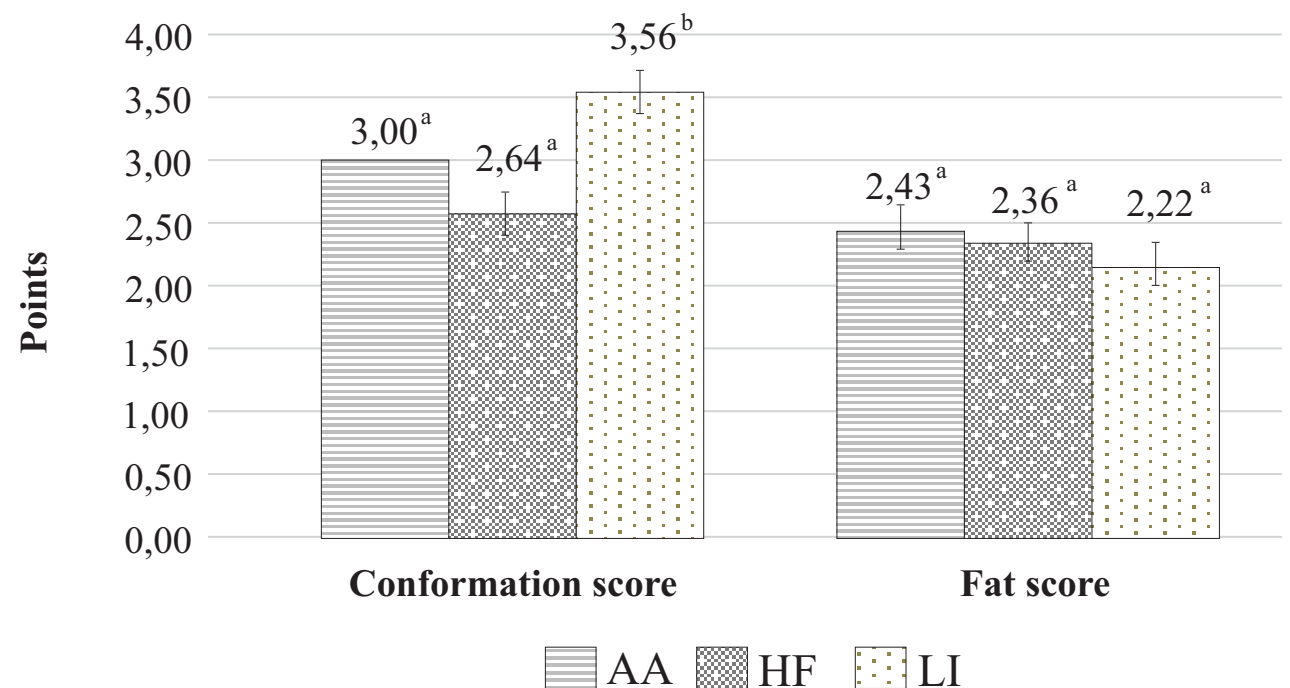

Figure 1. Average carcasses conformation and fatness results.

$\mathrm{a} b-$ significant differences between the study groups, $\mathrm{p}<0.05$

The evaluation of carcass fat class by breeds is not significantly different, but better fattened carcasses were obtained from AA breed bulls, on average $2.43 \pm 0.20$ points, but LI group bull carcasses had the lowest fat cover, evaluation $2.22 \pm 0.15$ points, difference was 0.21 points. The study by Pesonen \& Huuskonen (2015) concluded that British-type bulls were able to reach fat class 3 and 4 in the majority, while continental bulls had a higher percentage of fat class 2 , which is in line with the results of our study on obesity formation trends between breeds.

The results confirm that the bull breed had a significant effect on slaughter results, LI breed bulls had a higher slaughter weight, dressing percentage and conformation score, while AA and HF breed bull carcasses had a higher fat class score.

The chemical composition and $\mathrm{pH}$ value of $M$. longissimus muscle did not significantly differ among breeds
(Table 6). The average dry matter content of the samples was $28.0-28.8 \%$, total fat content $4.7-6.6 \%$, protein content $22.0-23.0 \%$, ash content $1.0-1.1 \%$, iron content $10.5-13.1$

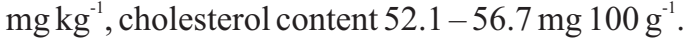

In the studies of other scientists, the dry matter content of M. longissimus muscle ranged from 20.52 to $26.84 \%$, total fat content from 1.10 to $4.42 \%$, protein content from 21.47 to 22.45 , ash content from 1.00 to $1.11 \%$, iron content from 14.2 to $22.03 \mathrm{mg} \mathrm{kg}^{-1}$ and cholesterol content from 50.86 to 88.00 mg per $100 \mathrm{~g}^{-1}$ (Brugiapaglia, Lussiana, \& Destefanis, 2014; De Marchi et al., 2007; Jemeljanovs et al., 2006; Mateescu et al., 2013; Mungure et al., 2020; Nogalski et al., 2018; Somogyi et al., 2015; Wheeler et al., 1987). In our study, a higher dry matter and total fat content was obtained, but an iron content was lower.

\section{Chemical composition and $\mathrm{pH}$ value of $M$. longissimus muscle in bulls of the breeds used in the study}

\begin{tabular}{|c|c|c|c|c|c|c|}
\hline \multirow{3}{*}{ Chemical composition } & \multicolumn{6}{|c|}{ Breed } \\
\hline & \multicolumn{2}{|c|}{$\mathrm{AA}(\mathrm{n}=7)$} & \multicolumn{2}{|c|}{$\mathrm{HF}(\mathrm{n}=11)$} & \multicolumn{2}{|c|}{ LI $(n=9)$} \\
\hline & $\mathrm{x} \pm \mathrm{Sx}$ & $\mathrm{V}, \%$ & $\mathrm{x} \pm \mathrm{Sx}$ & $\mathrm{V}, \%$ & $\mathrm{x} \pm \mathrm{Sx}$ & $\mathrm{V}, \%$ \\
\hline Moisture, \% & $71.3 \pm 0.8$ & 3.0 & $71.2 \pm 0.4$ & 2.0 & $72.0 \pm 1.0$ & 4.3 \\
\hline Fat, \% & $6.6 \pm 1.2$ & 47.5 & $6.5 \pm 0.5$ & 23.2 & $4.7 \pm 1.1$ & 70.1 \\
\hline Protein, \% & $22.0 \pm 0.4$ & 5.03 & $22.0 \pm 0.3$ & 3.9 & $23.0 \pm 0.2$ & 3.1 \\
\hline Ash, $\%$ & $1.0 \pm 0.0$ & 6.4 & $1.0 \pm 0.0$ & 5.7 & $1.1 \pm 0.0$ & 6.7 \\
\hline Cholesterol, mg $100 \mathrm{~g}^{-1}$ & $52.1 \pm 3.2$ & 16.1 & $52.8 \pm 2.0$ & 12.4 & $56.7 \pm 6.6$ & 35.0 \\
\hline
\end{tabular}




\begin{tabular}{|c|c|c|c|c|c|c|}
\hline Iron, $\mathrm{mg} \mathrm{kg}^{-1}$ & $13.1 \pm 0.6$ & 12.2 & $13.0 \pm 0.6$ & 15.3 & $10.5 \pm 1.1$ & 31.3 \\
\hline $\mathrm{pH}_{24}$ value & $6.0 \pm 0.1$ & 5.1 & $5.8 \pm 0.0$ & 4.3 & $5.8 \pm 0.1$ & 5.3 \\
\hline
\end{tabular}

Muscle samples of $M$. longissimus bulls of LI breed showed higher content of moisture $(72.0 \pm 1.0 \%)$, protein $(23.0 \pm 0.2 \%)$, ash $(1.1 \pm 0.0 \%)$ and cholesterol $(56.7 \pm 6.6 \mathrm{mg}$ $\left.100 \mathrm{~g}^{-1}\right)$. There was a large variation in fat, cholesterol and iron content, $70.1 \%, 35.0 \%$ and $31.3 \%$, respectively, which indicates a large variability in the results obtained.

Muscle samples from $M$. longissimus AA breed bulls showed higher total fat $(6.6 \pm 1.2 \%)$ and iron content $(13.1 \pm 0.6 \mathrm{mg})$. No significant differences between breeds were obtained.

In a Lithuanian study using purebred bulls slaughtered at 500 days of age (Jukna et al., 2017), compared to the results of our study, a lower dry matter content was obtained in $M$. longissimus muscle samples of all three breeds (AA bulls $24.26 \pm 0.11 \%$, HF bulls - $25.17 \pm 0.54 \%$, LI bulls $24.50 \pm 0.26 \%$ ). Like our study, the lowest total fat and the highest protein content were obtained in LI breed bull meat. The fat content was $1.24 \pm 0.15 \%$, but the protein content was $22.10 \pm 0.28$, which is $3.46 \%$ and $0.90 \%$ lower than in our study. The ash content ranged from $1.15 \%$ for LI and AA breeds to $1.20 \%$ for HF bull meat.

In a study conducted in Latvia (Jemeljanovs et al., 2006), using HF and LI breed meat samples (M. gluteus medius and $M$. longissimus dorsi), higher cholesterol content was obtained, respectively $64.06 \pm 2.07 \mathrm{mg}$ per $100 \mathrm{~g}^{-1} \mathrm{HF}$ breed and $63.29 \pm 1.69 \mathrm{mg}$ per $100 \mathrm{~g}^{-1}$ LI breed. The minimum cholesterol content was obtained in muscle samples of HF breed (58.93 mg $100 \mathrm{~g}^{-1}$ ) and LI breed (57.92 mg $100 \mathrm{~g}^{-1}$ ), which is more than the average cholesterol content obtained in our study for HF and LI breed bulls. In this study, the age of HF and LI breeds was lower than in our study, respectively,
HF breed cattle were slaughtered at $14.7 \pm 0.5$ months of age, and LI breed cattle at $12.8 \pm 1.17$ months of age.

The average $\mathrm{pH}$ value obtained in the study was $5.8 \pm 0.0$ for HF breed bull meat, $5.8 \pm 0.1$ for LI breed and $6.0 \pm 0.1$ for AA breed. The desired $\mathrm{pH}$ value for meat is in the range of 5.4 - 5.8. Such meat can be qualitatively matured, sold fresh or vacuum-packed and stored, it is visually attractive to the consumer, with good taste properties (Adzitey \& Huda, 2011). The maximum level has been reached for HF and LI breed bull meat and the maximum level has been exceeded for AA bull meat. It has been shown that bulls are more sensitive to pre-slaughter handling than heifers and steers, and this can lead to inappropriate $\mathrm{pH}$ value (Bures \& Barton, 2012; Cafferky et al., 2019). However, there are several studies confirming that AA, HF and LI breed bulls produce meat with a lower $\mathrm{pH}$ value than in our study (Jukna et al., 2017; Moran et al., 2019; Pesonen, Honkavaara \& Huuskonen, 2013a).

The correlations of the studied traits are expressed by the correlation coefficient and are summarized in Table 7. A strong positive correlation for AA and LI breed was obtained between such traits as cold carcass weight and dressing percentage, respectively $\mathrm{r}=0.90$ and $\mathrm{r}=0.88, \mathrm{p}<0.01$. For LI breed, a strong positive correlation was also observed between cold carcass weight and conformation score $(\mathrm{r}=0.98$, $\mathrm{p}<0.01)$. The obtained results of the correlation analysis show that as the carcass weight increases, the obtained dressing percentage increases and a positive trend is also observed for the LI breed regarding the conformation score. In the group of HF breed, the above-mentioned traits correlated positively with each other, showing average strong values $(p<0.05)$.

Table 7

\section{Slaughter traits correlation analysis}

\begin{tabular}{|c|c|c|c|c|}
\hline & \multirow{2}{*}{ Traits } & \multicolumn{3}{|c|}{ Group } \\
\hline & & $A A(n=7)$ & $\mathrm{HF}(\mathrm{n}=11)$ & $\mathrm{LI}(\mathrm{n}=9)$ \\
\hline \multirow{5}{*}{$\begin{array}{c}\text { Age before slaughter, } \\
\text { days }\end{array}$} & live weight before slaughter, $\mathrm{kg}$ & -0.16 & -0.10 & -0.53 \\
\hline & cold carcass weight, $\mathrm{kg}$ & -0.21 & 0.29 & $-0.72^{*}$ \\
\hline & dressing percentage, $\%$ & -0.15 & 0.47 & -0.56 \\
\hline & conformation score, points & - & 0.47 & $-0.74^{*}$ \\
\hline & fat score, points & -0.15 & -0.08 & 0.44 \\
\hline \multirow{4}{*}{$\begin{array}{l}\text { Live weight before } \\
\text { slaughter, } \mathrm{kg}\end{array}$} & cold carcass weight, $\mathrm{kg}$ & 0.38 & $0.68^{*}$ & 0.59 \\
\hline & dressing percentage, $\%$ & -0.07 & -0.01 & 0.13 \\
\hline & conformation score, points & - & 0.25 & 0.48 \\
\hline & fat score, points & -0.69 & -0.39 & -0.45 \\
\hline
\end{tabular}




\begin{tabular}{|c|c|c|c|c|}
\hline \multirow{4}{*}{ Cold carcass weight, $\mathrm{kg}$} & dressing percentage, $\%$ & $0.90^{* *}$ & $0.73^{*}$ & $0.88^{* *}$ \\
\cline { 2 - 5 } & conformation score, points & - & $0.69^{*}$ & $0.98^{* *}$ \\
\cline { 2 - 5 } & fat score, points & 0.71 & -0.02 & -0.52 \\
\hline
\end{tabular}

* - correlation is significant at the 0.05 level.

** - correlation is significant at the 0.01 level.

In LI breed bulls, the trait age before slaughter correlated average strong with the traits live weight before slaughter, cold carcass weight and conformation score. The obtained correlation values were negative and between the traits age before slaughter and cold carcass weight, as well as age before slaughter and conformation score, the correlation values were significant $(p<0.05)$.

For the AA breed, an average close correlation was for traits cold carcass weight and fat score, but for the live weight of HF and LI breed bulls with the cold carcass weight. Significant correlation was obtained for HF breed, $r=0.68$ $(\mathrm{p}<0.05)$

There was a weak, positive or negative correlation between the other slaughter traits. For the AA breed, it was not possible to perform a correlation analysis for conformation score, because the carcasses of all study animals received the same score -3.0 points.

\section{Conclusions}

The breed and age of the bulls used in the study before slaughter influenced the weight and dressing percentage of the cold carcass, as well as the conformation score. No significant effect on pre-slaughter live weight was observed.

The best slaughter results were shown by LI breed bulls, from which a significantly higher cold carcass weight of $301.1 \pm 6.8 \mathrm{~kg}(\mathrm{p}<0.05)$ was obtained, slaughter yield $58.2 \pm 1.1 \% \quad(\mathrm{p}<0.05)$ and conformation score $3.56 \pm 0.18$ points. The best fat class and according to this criterion, the best quality meat was obtained from AA breed bulls, evaluation $2.43 \pm 0.20$ points.

The breed, age and live weight of the bulls before slaughter did not significantly affect the chemical composition and $\mathrm{pH}$ of the meat, except for the protein content, which was significantly affected by breed and age before slaughter.

Muscle samples of $M$. longissimus from bulls of LI breed showed higher content of moisture $(72.0 \pm 1.0 \%)$, protein $(23.0 \pm 0.2 \%)$, ash $(1.1 \pm 0.0 \%)$ and cholesterol $(56.7 \pm 6.6 \mathrm{mg}$ $\left.100 \mathrm{~g}^{-1}\right)$. The highest total fat $(6.6 \pm 1.2 \%)$ and iron content $(13.1 \pm 0.6 \mathrm{mg})$ was obtained in AA breed bull muscle samples.

In the meat of bulls of HF and LI groups the maximum permissible $\mathrm{pH}$ value was reached, $5.8 \pm 0.0$ and $5.8 \pm 0.1$, respectively, but in the group of AA bulls the permissible limit was exceeded, $\mathrm{pH}$ value $6.0 \pm 0.1$.

The results of the correlation analysis varied between breeds. For AA and LI breed bulls, a significant, close positive correlation was obtained between cold carcass weight and dressing percentage $(\mathrm{r}=0.90$ and $\mathrm{r}=0.88)$. For LI breed bulls, there was also a close positive correlation between cold carcass weight and conformation score $(r=0.98, p<0.01)$

\section{References}

Adzitey, F., \& Huda, N. (2011). Pale soft exudative (PSE) and dark firm dry (DFD) meats: Causes and measures to reduce these incidences - A mini review. International Food Research Journal, 18(1), 11-20.

Biesalski, H. K. (2005). Meat as a component of a healthy diet - are there any risks of benefits if meal is avoided in the diet. Meat Science, 70(3), 509-524. DOI:10.1016/j.meatsci.2004.07.017.

Brugiapaglia, A., Lussiana, C., \& Destefanis, G. (2014). Fatty acid profile and cholesterol content of beef at retail of Piemontese, Limousin and Friesian breeds. Meat Science, 96(1), 568-573. DOI:10.1016/j.meatsci.2013.08.012.

Bures, D., \& Barton, L. (2012). Growth performance, carcass traits and meat quality of bulls and heifers slaughtered at different ages. Czech Journal of Animal Science, 57(1), 34-43. DOI:10.17221/5482-CJAS.

Cafferky, J., Hamill, R. M., Allen, P., O'Doherty, J. V., Cromie, A., \& Sweeney, T. (2019). Effect of breed and gender on meat quality of $M$. longissimus thoracis et lumborum muscle from crossbred beef bulls and steers. Foods, 8(5). DOI:10.3390/foods8050173.

Chassot, A., (2008). Die Rindfleischproduktion und die Umwelt (Beef production and the environment). Agrar Forschung, 15(10), 479. (In German).

Coyne, J. M., Evans, R. D., \& Berry, D. P. (2019). Dressing percentage and the differential between live weight and carcass weight in cattle are influenced by both genetic and non-genetic factors. Journal of Animal Science, 97(4), 1501-1512. DOI:10.1093/jas/skz056.

De Marchi, M., Berzaghi, P., Boukha, A., Mirisola, M., \& Gallo, L. (2007). Use of near infrared spectroscopy for assessment of beef quality traits. Italian Journal of Animal Science, 6(1s), 421-423.

DOI:10.4081/ijas.2007.1s.421.

Gagaoua, M., Terlouw, E. M. C., Micol, D., Hocquette, J. F., Moloney, A. P., Nuernberg, K., \& Picard, B. (2016). Sensory quality of meat from eight different types of cattle in relation with their biochemical characteristics. Journal of Integrative Agriculture, 15(7), 1550-1563. DOI:10.1016/S2095-3119(16)61340-0.

Giuffrida-Mendoza, M., Arenas de Moreno, L., UzcateguiBracho, S., Rincon-Villalobos, G., \& Huerta-Leidenz, N. (2007). Mineral content of longissimus dorsi thoracis from water buffalo and Zebu-influenced cattle at four comparative ages. Meat Science, 75(3), 487-493. DOI:10.1016/j.meatsci.2006.08.011.

Hickey, J. M., Keane, M. G., Kenny, D. A., Cromie, A. R. \& Veerkamp R. F. (2014). Genetic parameters for EUROP carcass traits within different groups of cattle in Ireland. Journal of Animal Science, 85(2), 314-321. DOI:10.2527/jas.2006-263.

Hollo G., Nuernberg K., Hollo I., Csapo J., Seregi J., Repa I., \& Ender K. (2007). Effect of feeding on the composition of longissimus muscle of Hungarian Grey and Holstein Friesian bulls. III. Amino acid composition and mineral content. Archiv fur Tierzucht, 50(6), 575-586. DOI:10.5194/aab-50-575-2007.. 
Hollo, G., Nuernberg, K., Somgyi, T., Istvan A., \& Hollo, I. (2012). Comparison of fattening performance and slaughter value of local Hungarian cattle breeds to international breeds. Tierzucht, 55(1), 1-12. DOI:10.5194/aab-55-1-2012.

Jemeljanovs, A., Nudiens, J., Dulbinskis, J., Sterna, V. (2006). Bioloǵiskajā lauksaimniecībā ražotās gaḷas kvalitāte un iespējamais mikrobiālais piesārnojums (Quality of organically produced meat and possible microbial contamination). LLU Biotehnologijas un veterinārmedicīnas zinātniskais institūts «Sigra», Sigulda, 128-140 lpp. (In Latvian).

Jukna, V., Jukna, C., Prusevicius, V., Meskinyte-Kausiliene, E., \& Peciulaitiene, N. (2017). Meat quality of different beef cattle breeds fed high energy forage. ZemdirbysteZemdirbyste, 104(3), 277-282.

DOI: 10.13080/z-a.2017.104.035.

Littledike, E. T., Wittum, T. E., \& Jenkins, T. G. (1995). Effect of breed, intake, and carcass composition on the status of several macro and trace minerals of adult beef cattle. Journal of Animal Science, 73(7), 2113-2119. DOI:10.2527/1995.7372113x.

Lopez-Alonso, M., Benedito, J. L., Miranda, M., Castillo, C., Hernandez, J., \& Shore, R. F. (2000). Arsenic, cadmium, lead, copper and zinc in cattle from Galicia, NW Spain. The Science of the Total Environment, 246(2-3), 237-248.

DOI:10.1016/S0048-9697(99)00461-1.

Mateescu, R. G., Garmyn, A. J., Tait, J. G., Duan, Q., Liu, Q., Mayes, M. S., ... Reecy, J. M. (2013). Genetic parameters for concentrations of minerals in longissimus muscle and their associations with palatability traits in angus cattle. Journal of Animal Science, 91(3), 1067-1075. DOI:10.2527/jas.2012-5744.

Moran, L., Wilson, S. S., McElhinney, C. K., Monahan, F. J., McGee, M., O'Sullivan, M. G., ... Moloney, A. P. (2019). Suckler bulls slaughtered at 15 months of age: Effect of different production systems on the fatty acid profile and selected quality characteristics of Longissimus thoracis. Foods, 8(7):264, 1-17. DOI:10.3390/foods 8070264.

Muizniece, I., \& Kairisa, D. (2016). Different beef breed cattle fattening results analysis. In Research for Rural Development 2016: 22nd Annual International Scientific Conference, 18 - 20 May 2016, (Vol. 1, pp. 57-62). Jelgava: Latvia University of Life Sciences and Technologies.

Mungure, T. E., Birch, E. J., Ponnampalam, E. N., Stewart, I., Ahmed, I. A. M., Al-Juhaimi, F. Y., \& Bekhit, A. E. D. A. (2020). Conjugated linoleic acid and cholesterol oxidative products generated in hot boned beef semimembranosus muscle as affected by rigor temperature, ageing and display time. Foods, 9(1). DOI: $10.3390 /$ foods 9010043 .

Nogalski, Z., Wielgosz-Groth, Z., Purwin, C., Nogalska, A., Sobczuk-Szul, M., Winarski, R., \& Pogorzelska, P. (2014). The effect of slaughter weight and fattening intensity on changes in carcass fatness in young Holstein-Friesian bulls. Italian Journal of Animal Science, 13(1), 66-72. DOI:10.4081/ijas.2014.2824.

Nogalski, Z., Pogorzelska-Przybylek, P., Sobczuk-Szul, M., Nogalska, A., Modzelewska-Kapitula, M., \& Purwin, C. (2018). Carcass characteristics and meat quality of bulls and steers slaughtered at two different ages. Italian
Journal of Animal Science, 17(2), 279-288.

DOI:10.1080/1828051X.2017.1383861.

Nohr, D. \& Biesalski, H.K. (2007)“"Mealthy food": meat as a healthy and valuable source of micronutrients. Animal, 1, 309-316. DOI: 10.1017/S1751731107657796.

Pesonen, M., Honkavaara, M., \& Huuskonen, A. (2013a). Production, carcass and meat quality traits of Hereford, Charolais and Hereford $\times$ Charolais bulls offered grass silage-grain-based rations and slaughtered at high carcass weights. Acta Agriculturae Scandinavica A: Animal Sciences, 63(1), 28-38. DOI:10.1080/09064702.2013.777091.

Pesonen, M., Honkavaar, M., Kämäräinen, H., Tolonen, T., Jaakkola, M., Virtanen, \& V., Huuskonen, A. (2013b). Effects of concentrate level and rapeseed meal supplementation on performance, carcass characteristics, meat quality and valuable cuts of Hereford and Charolais bulls offered grass silage-barleybased rations. Agricultural and Food Science, 22(1), 151-167. DOI:10.23986/afsci.6703

Pesonen, M., \& Huuskonen, A. (2015). Production, carcass characteristics and valuable cuts of beef breed bulls and heifers in Finnish beef cattle population. Agricultural and Food Science, 24(3), 164-172.

DOI:10.23986/afsci.50930.

Sexten, A. K., Krehbiel, C. R., Dillwith, J. W., Madden, R. D., McMurphy, C. P., Lalman, D. L., \& Mateescu, R. G. (2012). Effect of muscle type, sire breed, and time of weaning on fatty acid composition of finishing steers. Journal of Animal Science, 90(2), 616-625. DOI:10.2527/jas.2011-4218.

Somogyi, T., Hollo, I., Csapo, J., Anton, I., \& Hollo, G. (2015). Mineral content of three several muscles from six cattle genotypes. Acta Alimentaria, 44(1), 51-59. DOI:10.1556/AAlim.44.2015.1.4

Stimbirys A., Sherniene L., V. Prusevichus V., Jukna V., Shimkus Al., \& Shimkiene Al. (2016) The influence of different factors on bulls carcass conformation class in Lithuania. Bulgarian Journal of Agricultural Science, 22(4), 627-634.

Tizioto, P. C., Taylor, J. F., Decker, J. E., Gromboni, C. F., Mudadu, M. A., Schnabel, R. D., Coutinho, L. L., Mourao, G. B., Oliveira, P. S. N., Souza, M. M., Reecy, J. M., Nassu, R. T., Bressani, F. A., Tholon, P., Sonstegard, T. S., Alencar, M. M., Tullio, R. R., Nogueira, A. R. A., \& Regitano, L. C.A. (2015). Detection of quantitative trait loci for mineral content of Nelore longissimus dorsi muscle. Genetics Selection Evolution, 47(1). DOI:10.1186/s12711-014-0083-3.

Toro, P., Catrileo, A., Aguilar, C., \& Vera, R. (2009). Modeling supplementation strategies for beef steer rearing and fattening system in Southern Chile. Chilean journal of agricultural research, 69(2), 207-213.

Wheeler, T., Davis, G., Stoecker, B., \& Harmon, C. (1987). Cholesterol concentration of longissimus muscle, subcutaneous fat and serum of two beef cattle breed types. Journal of Animal Science, 65, 1531-1537. DOI:10.2527/jas 1987.6561531x. 


\section{Acknowledgement}

The research was carried out at the Latvia University of Life Sciences and Technologies project No. Z20 'Beef cattle and their crossbreed suitability for fattening with grass forage'.

Thanks to SIA Baltic Vianco Trading (Latvia) and UAB Baltic Vianco Trading (Lithuania) for the selection of bulls required for the project and to the slaughterhouse UAB 'Agaras' (Lithuania) for the preparation of samples required for the analysis of chemical composition. 